\title{
Ground motion prediction equation for West Sumatra due to distant shallow crustal, interface, andilntraslab warthquakes
}

\author{
Sidiq Hargo Pandadaran ${ }^{1, *}$, George Francisco Augusto Muabuay ${ }^{1}$, Sigit Eko Kurniawan ${ }^{1}$ and Muhamad Fadhilah $^{1}$ \\ ${ }^{1}$ Meteorological, Climatological, and Geophysical Agency,10720 Kemayoran, Jakarta Pusat, Indonesia
}

\begin{abstract}
Ground motion prediction equation (GMPE) is an important component for seismic hazard study to minimize the casualty from an earthquake, especially in the building collapse. This study presents ground motion prediction equation for West Sumatra due to distant shallow crustal, interface, and intraslab earthquakes. The data sets consist of 375 strong motion data that are recorded by Meteorological, Climatological, and Geophysical Agency's (BMKG) accelerograph sensors that located in West Sumatra, earthquake parameter data are from BMKG's earthquakes catalog with the range moment magnitude of 4.0-6.4 and recorded at sites with hypocentral distance of $17-1000 \mathrm{~km}$, focal mechanism data are from Global Centroid Moment Tensor (GCMT), and use site classification to enhance the quality of the results. This study shows good results with the standard deviation of residual value of 0.23 for shallow crustal, 0.29 for interface, and 0.49 for intraslab earthquakes.
\end{abstract}

\section{Introduction}

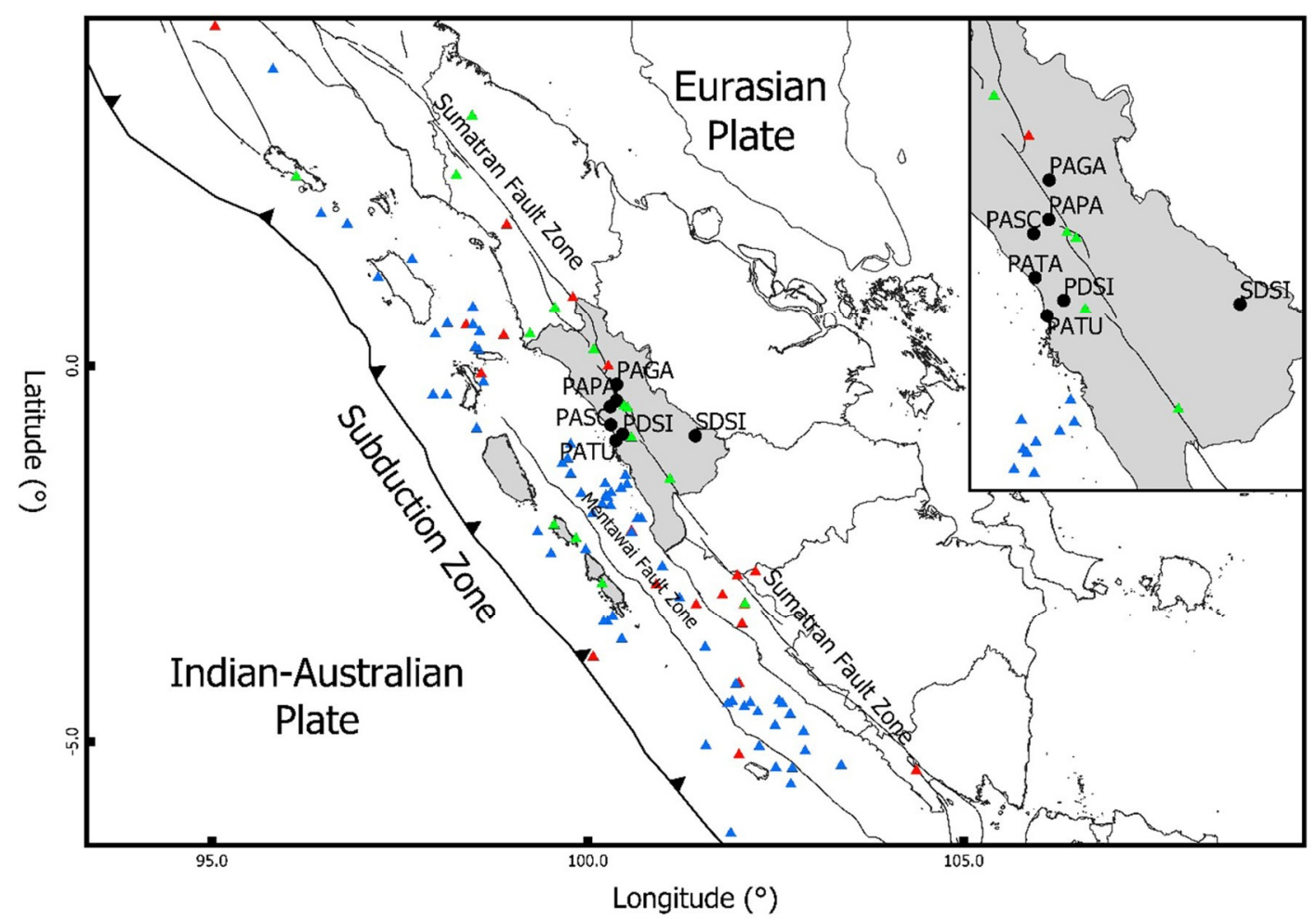

Fig. 1. Accelerograph sensors (illustrated by black circle), shallow crustal events (illustrated by green triangle), subduction interface events (illustrated by blue triangle), and subduction intraslab events (illustrated by red triangle).

Ground motion prediction equation (GMPE) is an important part in terms of seismological engineering and probabilistic seismic hazard analysis (PSHA). Recently there are many GMPE models published, such as the model is used by GMPE from the Next Generation Attenuation (NGA) model that originated from Califor-

\footnotetext{
* Corresponding author: sidiqargo@gmail.com
} 

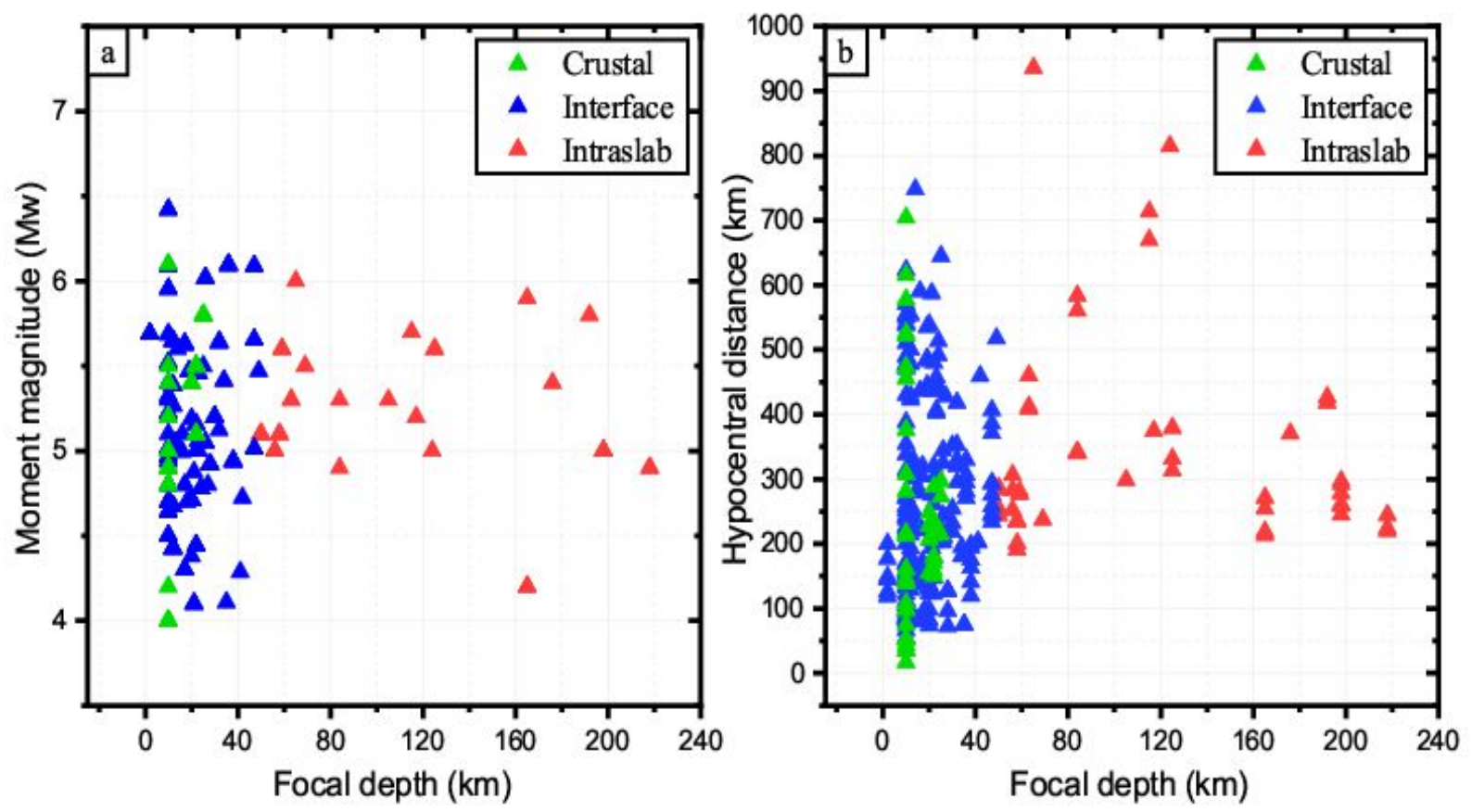

Fig. 2. Distribution data of (a) Moment magnitude-focal depth and (b) Hypocentral distance-focal depth.

nia's strong motion data and enhanced with shallow crustal records from Japan, Turkey, and Taiwan. The tectonic condition in each region is varied. The difference in tectonic conditions creates a different level of ground motion when the earthquake occurs. Therefore, the GMPE model is needed for each type of tectonic condition. Zhao et al. (2006) created GMPE model for shallow crustal, subduction interface, and subduction intraslab earthquakes. They made the GMPE formula for Japan and used Vs30 for site classification as supporting data. So, the results were more accurate.

West Sumatra is one of Indonesia's provinces that has earthquakes frequently. The earthquakes are triggered because of there is a collision between two world plates named Eurasian and Indian-Australian plates, Sumatra fault activities, and Mentawai fault activities. There were at least 30 destructive earthquakes in West Sumatra from 1821-2017 and 6 of them caused tsunamis, there were earthquakes on 5th July 1904 (there was no information about the magnitude), 10th April 2005 with Mw 6.7, 30th September 2009 with Mw 7.6, 16th August 2009 with Mw 6.9, 25th October 2010 with Mw 7.2, and 2nd March 2016 with Mw 7.8 [10]. The worst is caused by the earthquake on 30th September 2009 with Mw 7.6 felt by MMI VII in the city of Padang, West Sumatra with a $20 \mathrm{~cm}$ height of the tsunami. Although it was not too high, it made 1115 victims because of building collapse.

This study discusses GMPE that is appropriate for West Sumatra province due to distant shallow crustal, subduction and subduction intraslab earthquakes by adopting the basic model from Zhao et al. [8], then modify the coefficients to get the model which is appropriate for West Sumatra province. Due to frequent earthquakes and the lack of accelerograph sensors in it, to minimize the impact, especially in the manu- facture of earthquake-resistant buildings, research on GMPE needs to be done. So, the model obtained can be used as supporting data to make earthquake-resistant buildings.

\section{Data}

In this study, the number of recorded ground motion data is limited. However, based on the limited data for a given magnitude and distance, there is no significant difference between the earthquakes induced ground motion due to different subduction regions [2].

The ground motion database in this study is obtained from Meteorological, Climatological, and Geophysical Agency's (BMKG) accelerograph sensors that are located in West Sumatra with 375 ground motion data records. There are seven accelerograph sensors used in this study (Fig. 1), named PAGA, PAPA, PASC, PATA, PATU, PDSI, and SDSI. BMKG's accelerograph data are classified by Vs30 that is calculated by the average time of shear wave velocity at a depth of $30 \mathrm{~m}$. PASC and SDSI are located in Sicincin and Sungai Dareh with site classification NEHRP C, PAGA, PAPA, PATA, and

Table 1. Site classification.

\begin{tabular}{llll}
\hline $\begin{array}{l}\text { Site } \\
\text { Classes }\end{array}$ & Description & $\mathbf{V}_{\mathrm{s} 30}(\mathbf{m} / \mathbf{s})$ & $\begin{array}{l}\text { NEHRP } \\
\text { Site } \\
\text { Classes }\end{array}$ \\
\hline Hard rock & & $\mathrm{V}_{\mathrm{s} 30}>1100$ & $\mathrm{~A}$ \\
SC I & Rock & $\mathrm{V}_{\mathrm{s} 30}>600$ & $\mathrm{~A}+\mathrm{B}$ \\
SC II & Hard soil & $\begin{array}{l}300<\mathrm{V}_{\mathrm{s} 30} \leq \\
600\end{array}$ & $\mathrm{C}$ \\
& & $200<\mathrm{V}_{\mathrm{s} 30} \leq$ & $\mathrm{D}$ \\
SC III & Medium soil & 300 & \\
SC IV & Soft soil & $\mathrm{V}_{\mathrm{s} 30} \leq 200$ & $\mathrm{E}+\mathrm{F}$ \\
\hline
\end{tabular}



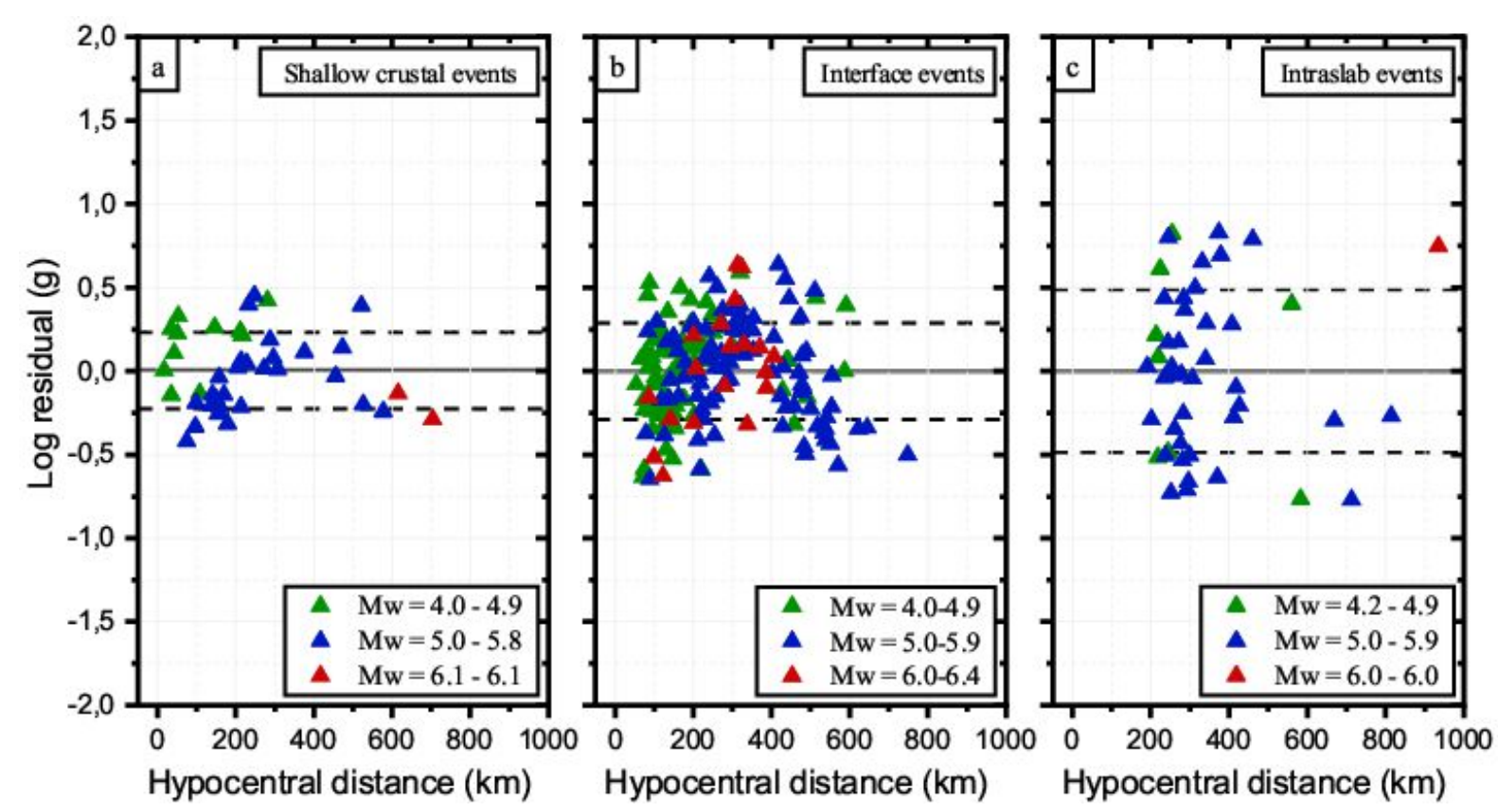

Fig. 3. Residual distribution by this study for (a) Shallow crustal events, (b) Interface events, and (c) Intraslab events

PDSI are located in Bukit Tinggi, Padang Panjang Ketaping, and the city of Padang with site classification NEHRP D, and PATU that is located in Teluk Bayur with site classification NEHRP E. Earthquake parameter data are from BMKG's earthquakes catalog with the range moment magnitude $(\mathrm{Mw})$ of 4.0-6.4 and recorded at sites at hypocentral distance of $17-1000 \mathrm{~km}$, the distribution data of moment magnitude-focal depth and hypocentral distance-focal depth are in Fig. 2. The information about focal mechanism data is obtained from Global Centroid Moment Tensor (GCMT) and for the site classification information by Zhao et al. [8] that approximately corresponding to NEHRP site classes [3] that can be seen in Table 1. The formula for magnitude conversion comes from Pusat Studi Gempa Nasional [11] that can be seen in equation (1), (2), and (3).

$$
M w=1,0107 m b+0.0801
$$

$$
\begin{gathered}
M w=0.6016 M s+2.476 \text { for } 2.8 \leq M s \leq 6.1 \\
M w=0.9239 M s+0.5671 \text { for } 6.2 \leq M s \leq 8.7
\end{gathered}
$$

Where $\mathrm{Mw}$ is the moment magnitude, mb is body wave magnitude, and Ms is surface wave magnitude. There is no equation for local magnitude $(\mathrm{ml})$ because there is no significant difference between $\mathrm{Mw}$ and $\mathrm{ml}$. So $\mathrm{ml}$ is assumed to represent $\mathrm{Mw}$ [11].

\section{Method}

The basic model from Zhao et al. [8] is adopted in his study. The coefficients of the basic model are modified, so that is appropriate to be applied in West Sumatra, especially for distant shallow crustal, interface, and intraslab earthquake sources. The model is defined as follows :

$$
\begin{gathered}
\log _{\mathrm{e}}\left(y_{\mathrm{i}, \mathrm{j}}\right)=a M_{w \mathbf{i}}+b x_{\mathrm{i}, \mathbf{j}}-\log _{\mathrm{e}}\left(r_{\mathrm{i}, \mathrm{j}}\right)+e\left(h-h_{c}\right) \delta_{h} \\
+F_{R}+S_{I}+S_{S}+S_{S L} \log _{\mathrm{e}}\left(x_{\mathrm{i}, \mathrm{j}}\right)+C_{k} \\
r_{\mathrm{i}, \mathbf{j}}=x_{\mathbf{i}, \mathbf{j}}+c \exp \left(d M_{w \mathbf{i}}\right)
\end{gathered}
$$

Where y is peak ground acceleration (PGA) in centimeters/second $2(\mathrm{~cm} / \mathrm{s} 2)$ from the geometric mean of two horizontal components. Mw is the moment magnitude, $\mathrm{x}$ is the hypocentral distance in kilometers $(\mathrm{km})$, and $\mathrm{h}$ is the focal depth in kilometers $(\mathrm{km})$. FR is reverse fault parameter applies only for shallow crustal events with a reverse fault mechanism and zero for the other events, SI is tectonic source type parameter applies only for interface event and zero for the other events, SS applies only for subduction slab events and zero for the other events, SSL is a magnitude independent path modification term for slab event to compensate the complexity of travel path from slab events and zero for the other events, and $\mathrm{Sk}$ is site classification term. Subscript $i$ is event number and $j$ is the number of recorded pga of event $i . h_{c}$ is the best depth coefficient for shallow events, where $h_{c}=15 \mathrm{~km}$. $\delta h$ is the dummy variable that equals 1 when $h$ is larger than $h_{c}$, and 0 for the other events. When $\mathrm{h}$ is deeper than $125 \mathrm{~km}, \mathrm{~h}=125$ $\mathrm{km}$ becomes a constant factor for deep earthquakes or it is capped at $125 \mathrm{~km}$. Coefficients a, b, c, d, e, FR, SI, SS, SSL, SK can be calculated by regression analysis.

The GMPE model is good if the results are close to observation data. Therefore evaluation is needed to prove it. Residual value is calculated to find out how far the difference between the results of the prediction to the observation data. This study uses a standard deviation of residual value ( $\sigma$ res) to find the average residual distribution value between the pga prediction and the observation data. Root mean square error (RMSE) is selected to compare the average error value 


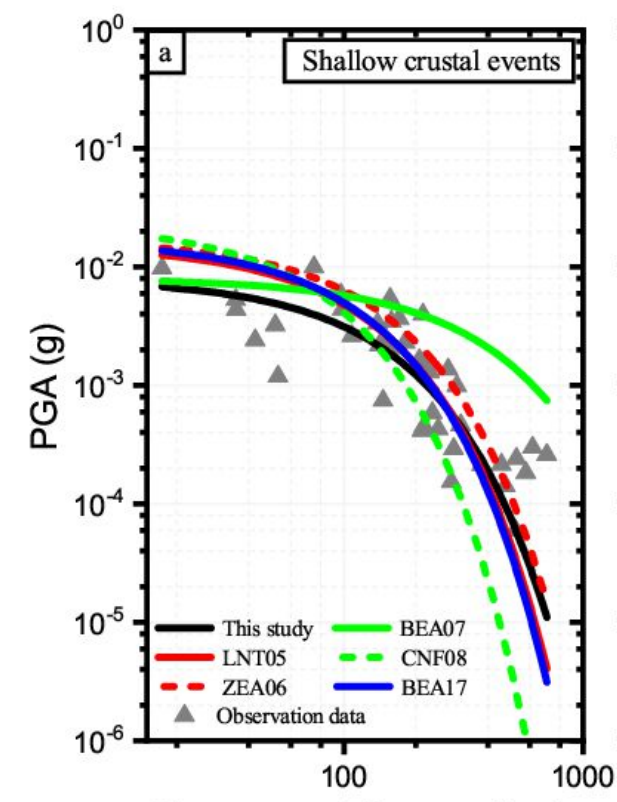

Hypocentral distance $(\mathrm{km})$

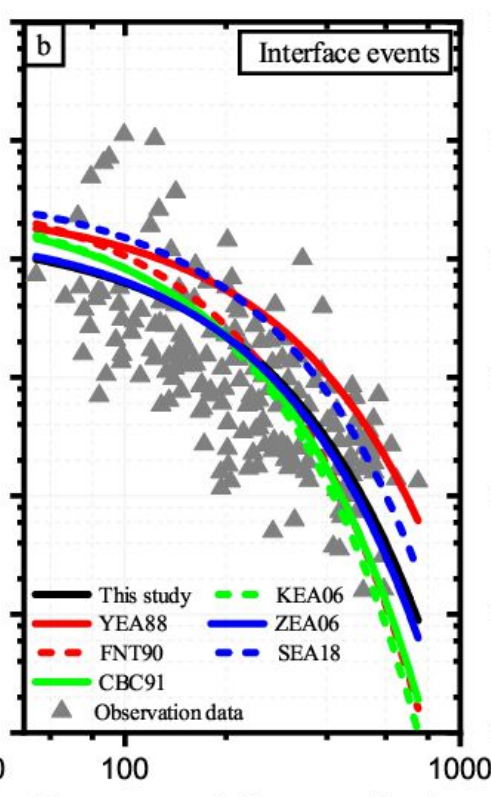

Hypocentral distance $(\mathrm{km})$

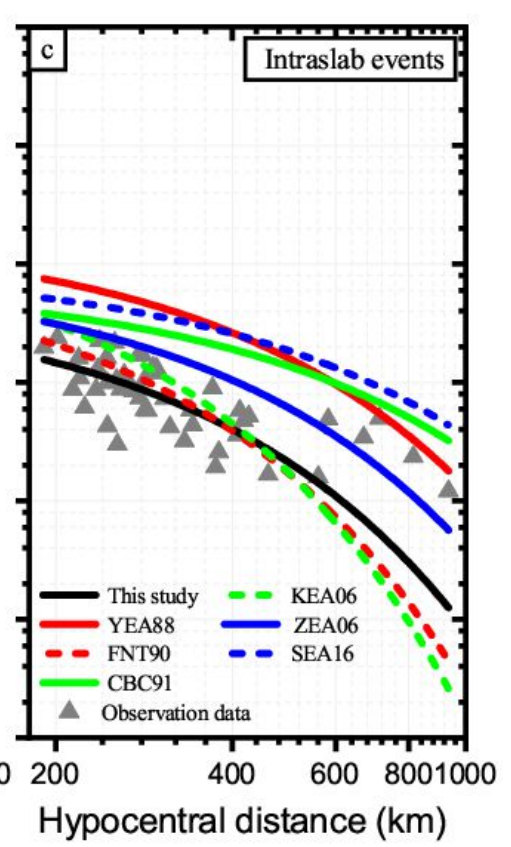

Fig. 4. Distribution of pga prediction from normalized pga by this study compared to other studies for (a) shallow crustal events, (b) subduction interface events, and (c) subduction intraslab events

of this study to other studies so that it could be known whether a study is good or not. The equations of the standard deviation of residual value and root mean square error are in equations (6) and (7).

$$
\begin{gathered}
\sigma_{\text {res }}=\sqrt{\frac{\sum_{j=I}^{n}\left(r_{j}-r_{\text {average })^{2}}\right.}{n-1}} \\
R M S E=\sqrt{\frac{\sum_{j=1}^{n}\left(y_{\text {pre }}-y_{\text {obs }}\right)^{2}}{n}}
\end{gathered}
$$

Where $r$ is the residual value between pga prediction and pga observation, $y$ is the peak ground acceleration, subscript $\mathrm{j}$ is the number of recorded pga, and $\mathrm{n}$ is the total number of recorded pga.

\section{Results}

On its application, GMPE is used to predict the ground motion value in the area that is lacked or there are no accelerograph sensors, making probabilistic seismic hazard analysis (PSHA) maps to predict the value of ground motion in the future and become supporting data to make earthquake-resistant buildings.

Many models of GMPE have been produced in these decades. GMPE models with the source of shallow crustal earthquakes among others are Liu and Tsai [9], Zhao et al. [8], Bindi et al. [6], Cauzzi and Faccioli [5], and Bindi et al. [7] and GMPE models with subduction interface and intraslab earthquake sources are Young et al. [12], Fukushima and Tanaka [14], C. B. Crouse [4], Kanno et al. [13], Zhao et al. [8], Shoushtari et al. [1], and Shoushtari et al. [2]. The summary of those GMPE models is in Table 2. After regressing all the data, the modified coefficients are obtained (Table 3 ).

Based on the table, the standard deviation of residual
Table 3. Modiffied coefficients by this study

\begin{tabular}{cccc}
\hline Coefficients & $\begin{array}{c}\text { Shallow } \\
\text { Crustal }\end{array}$ & Interface & Intraslab \\
\hline $\mathrm{a}$ & 0.9215 & 1.9263 & 0.3188 \\
$\mathrm{~b}$ & -0.00402 & -0.00583 & 0.00327 \\
$\mathrm{c}$ & 0.0055 & 0.0055 & 0.0055 \\
$\mathrm{~d}$ & 1.080 & 1.080 & 1.080 \\
$\mathrm{e}$ & -0.00532 & -0.0128 & -0.00222 \\
$\mathrm{~F}_{\mathrm{R}}$ & 0.4005 & - & - \\
$\mathrm{S}_{\mathrm{I}}$ & - & -4.35125 & - \\
$\mathrm{S}_{\mathrm{S}}$ & - & - & 12.94851 \\
$\mathrm{~S}_{\mathrm{SL}}$ & - & - & -2.00139 \\
$\mathrm{~S}_{3}$ & 1.355 & 1.355 & 1.355 \\
$\mathrm{~S}_{4}$ & 1.420 & 1.420 & 1.420 \\
$\sigma_{\mathrm{res}}$ & 0.23 & 0.29 & 0.49 \\
\hline
\end{tabular}

value and root mean square error are chosen. From that table, the standard deviation of residual value for shallow crustal events are 0.23 , subduction interface events are 0.29 , and for subduction intraslab are 0.49 . Site classification terms from Zhao et al. [8] that are used in this study are SC III and SC IV because the accelerograph sensors are only in sites D and $\mathrm{E}$.

The residuals distribution of ground motion prediction equation due to distant shallow crustal, interface, and intraslab earthquakes are presented in Fig. 3. The residuals are in a logarithmic unit that explains the difference between the log predicted pga and the log observed pga. All the models are divided into three and the standard deviation of residual value in dash line. Fig. 4 shows the pga predictions compared to other studies. From that figure, this study always has the lowest trend 


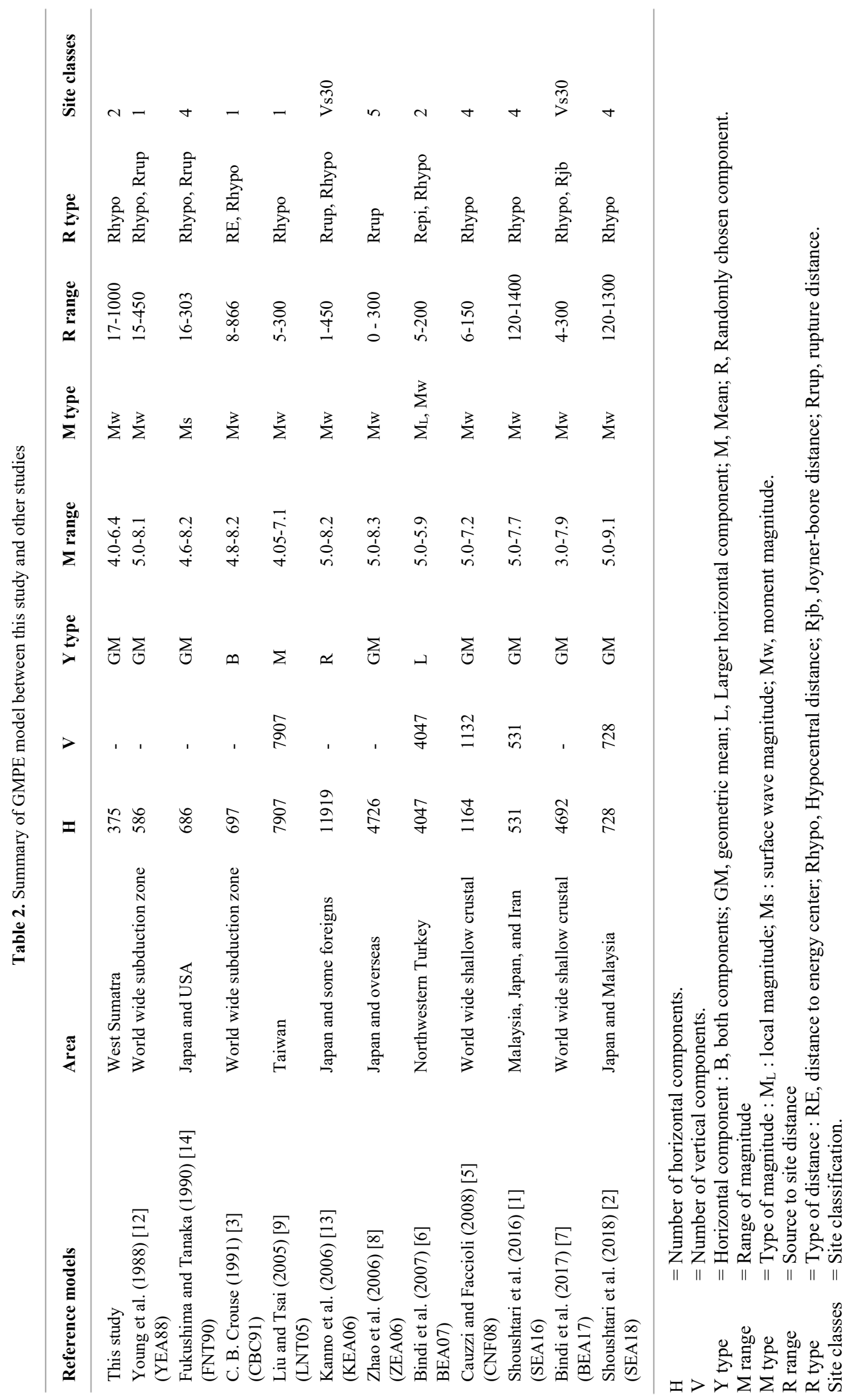


Table 4. RMSE value from all the reference models

\begin{tabular}{lccc}
\hline Reference Models & Shallow crustal & Interface & Intraslab \\
\hline This study & 0.22 & 0.29 & 0.21 \\
Young et al. (1988) [12] & - & 0.71 & 0.73 \\
Fukushima and Tanaka (1990) [14] & - & 0.46 & 0.50 \\
C.B. Crouse (1991) [3] & - & 0.37 & 0.54 \\
Liu and Tsai (2005) [9] & 0.31 & - & - \\
Kanno et al. (2006) [13] & - & 0.39 & 0.56 \\
Zhao et al. (2006) [8] & 0.36 & 0.38 & 0.50 \\
Bindi et al. (2007) [6] & 0.61 & - & - \\
Cauzzi and Faccioli (2008) [5] & 0.40 & - & - \\
Shoushtari et al. (2016) [1] & - & - & 0.65 \\
Bindi et al. (2017) [7] & 0.38 & - & - \\
Shoushtari et al. (2018) [2] & - & 0.65 & - \\
\hline
\end{tabular}

line predictions on three types of earthquake sources, especially on the hypocentral distance that less than 130 $\mathrm{km}$ for shallow crustal and subduction interface earthquakes, while for the subduction intraslab is less than $300 \mathrm{~km}$. For the closest recorded earthquakes, for shallow crustal with Mw 4.2 and at hypocentral distance of $17 \mathrm{~km}$, this study predicts pga values of $0.009 \mathrm{~g}$, for subduction interface with $\mathrm{Mw} 4.7$ and at hypocentral distance of $54 \mathrm{~km}$ pga predictions of $0.007 \mathrm{~g}$, and for the subduction intraslab earthquake sources, at hypocentral distance of $191 \mathrm{~km}$ with $\mathrm{Mw} 5.1$ pga predictions of $0.002 \mathrm{~g}$.

The largest earthquake with $\mathrm{Mw} 6.1$ for shallow crustal with a hypocentral distance of about $600 \mathrm{~km}$ is recorded at site $\mathrm{D}$ sensors with the pga prediction about $0.0003 \mathrm{~g}$. Then, for subduction interface earthquakes with the largest $\mathrm{Mw} 6.4$ with a hypocentral distance of $300 \mathrm{~km}$ is recorded at site D sensors with pga prediction around $0.003 \mathrm{~g}$ and the largest subduction intraslab earthquake with $\mathrm{Mw} 6.0$ is recorded at site D with a hypocentral distance of $935 \mathrm{~km}$, the pga prediction is $0.0001 \mathrm{~g}$.

Pga prediction at site $\mathrm{E}$ is always higher than site $\mathrm{D}$, because of the site amplification effect which makes the ground motion higher on softer soils for all the earthquake sources. For example, the shallow crustal earthquake with $\mathrm{Mw} 5.0$, site $\mathrm{D}$ sensor with a hypocentral distance of $96 \mathrm{~km}$, this study predicts the pga with $0.0027 \mathrm{~g}$ while the site $\mathrm{E}$ at a hypocentral distance of $98 \mathrm{~km}$, the pga prediction is $0.0028 \mathrm{~g}$, and it is also applied to subduction interface and intraslab sources.

Compared to other studies, this study has RMSE value of 0.22 for shallow crustal, 0.29 for subduction interface, and 0.21 for subduction intraslab earthquakes (Table 4). The basic formula from Zhao et al. [8] has 0.36 for shallow crustal, 0.38 for subduction interface, and 0.50 for subduction intraslab events. The difference in using data, such as the magnitude range, distance range, and tectonic complexity, may affect the results of the prediction.

\section{Conclusions and recommendations}

GMPE is one of the important components of seismic hazard study. Its role is as additional information in the construction of earthquake-resistant buildings and PSHA maps will be useful in the future.

This study provides an update GMPE models for distant shallow crustal, subduction interface and subduction intraslab earthquakes especially for West Sumatra by adopting the basic model from Zhao et al. [8]. The data contain earthquakes moment magnitude with the range of 4.0-6.4, recorded at sites with hypocentral distance of 17-1000 km, and using two soil classification named NEHRP site D and E. The results that are obtained from this study may be different compared to GMPE which used closer distance, since it is not the scope of this study, as well as Zhao et al. [8] which is less than $300 \mathrm{~km}$.

Hopefully, this research can be used for seismic hazard study in West Sumatra, especially for distant earthquakes to reduce the impact. If there are many recording data in the future and the data are available for all site classes, further updates need to be made regarding the existing formula.

Authors want to acknowledge Meteorological, Climatological, and Geophysical Agency (BMKG) for the supporting data and an extended thanks to Linia Amin Nintia for editing this manuscript to ensure the compatibility.of the language.

\section{References}

1. A. V. Shoushtari, A. B. Adnan, M. Zare, Soil Dynam. Earthq. Eng. 82, 123-137, (2016)

2. A. V. Shoushtari, A. Z. Adnan, M. Zare, Soil Dynam. Earthq. Eng. 109, 339-353 (2018)

3. Building Seismic Safety Council, FEMA 368/369 
(2000)

4. C. B. Crouse, Earthq. Spectra. 7, 201-236 (1991)

5. C. Cauzzi, E. Faccioli, J. Seismol. 12, 453-475 (2008)

6. D. Bindi, S. Parolai, H. Grosser, C. Milkereit, and E. Durukal, Geo. Res. Letters. 34 (2007)

7. D. Bindi, F. Cotton, S. R. Kotha, C. Bosse, D. Stromeyer, G. Grünthal, J. Seismol. 21, 1201-1218 (2017)

8. J. X. Zhao, J. Zhang, A. Asano, Y. Ohno, T. Oouchi, T. Takahashi, H. Ogawa, K. Irikura, H. K. Thio, P. G. Somerville, Y. Fukushima, Y. Fukushima, Bul. Seismol. Soc. Am. 96, 898-913 (2006)
9. K. S. Liu, Y. B. Tsai, Bul. Seismol. Soc. Am. 95, 1045-1058 (2005)

10. Pusat Gempa bumi dan Tsunami, Katalog gempa bumi signifikan dan merusak 1821 - 2017 (2018)

11. Pusat Studi Gempa Nasional, Peta sumber dan bahaya gempa Indonesia tahun 2017 (2017)

12. R. R. Youngs, S. M. Day, J. L. Stevens, In Proc. Earthq. Eng. Soil Dynam. II. 445-462 (1988)

13. T. Kanno, A. Narita, N. Morikawa, H. Fujiwara, Y. Fukushima, Bul. Seismol. Soc. Am. 96, 879897 (2006)

14. Y. Fukushima and T. Tanaka, Bul. Seismol. Soc. Am. 80, 757-783 (1990) 